\title{
Integrating and Controlling ICT Implementation in the Supply Chain: The SME Experience from Baja California
}

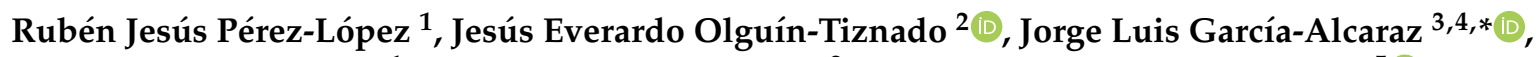 \\ María Mojarro-Magaña ${ }^{1}$, Claudia Camargo-Wilson ${ }^{2}$ and Juan Andrés López-Barreras ${ }^{5}$ (D) \\ 1 Department of Industrial Engineering, Technological Institute of Ciudad Guzmán, \\ Ciudad Guzmán 49100, Mexico; ruben.pl@cdguzman.tecnm.mx (R.J.P.-L.); \\ maria.mm@cdguzman.tecnm.mx (M.M.-M.) \\ 2 Faculty of Engineering, Architecture, and Design, Autonomous University of Baja California, \\ Ensenada 22860, Mexico; jeol79@uabc.edu.mx (J.E.O.-T.); ccamargo@uabc.edu.mx (C.C.-W.) \\ 3 Department of Industrial Engineering and Manufacturing, Autonomous University of Ciudad Juárez, \\ Ciudad Juárez 32310, Mexico \\ 4 Division of Research and Postgraduate Studies, Tecnológico Nacional de México/Instituto Tecnológico de \\ Ciudad Juárez, Ciudad Juárez 32500, Mexico \\ 5 Faculty of Engineering and Chemical Sciences, Autonomous University of Baja California, \\ Tijuana 22390, Mexico; jalopez@uabc.edu.mx \\ * Correspondence: jorge.garcia@uacj.mx or jorge.ga01@itcj.edu.mx; Tel.: +52-656-6884843 (ext. 5433)
}

Citation: Pérez-López, R.J.; Olguín-Tiznado, J.E.; García-Alcaraz, J.L.; Mojarro-Magaña, M.;

Camargo-Wilson, C.; López-Barreras, J.A. Integrating and Controlling ICT Implementation in the Supply Chain: The SME Experience from Baja California. Mathematics 2021, 9, 1234. https://doi.org/10.3390/ math9111234

Academic Editor: María del Carmen Valls Martínez

Received: 30 April 2021

Accepted: 25 May 2021

Published: 28 May 2021

Publisher's Note: MDPI stays neutral with regard to jurisdictional claims in published maps and institutional affiliations.

Copyright: (c) 2021 by the authors. Licensee MDPI, Basel, Switzerland. This article is an open access article distributed under the terms and conditions of the Creative Commons Attribution (CC BY) license (https:// creativecommons.org/licenses/by/ $4.0 /)$.
Abstract: It is mentioned that companies' competition is currently more associated with supply chains (SC) than production processes since sometimes logistics costs represent up to $70 \%$ of the total production cost in a product. To improve efficiency in SC, companies are implementing information and communication technologies (ICT). This paper reports a structural equation model that incorporates four latent variables related to ICT applied in SC: technological innovation, information management, and information availability as independent variables, and operating benefits gained as a dependent variable. These variables are related using six hypotheses that are validated using information obtained from 80 responses to a survey applied to small and medium-sized enterprises in Baja California (Mexico). The partial least squares technique is used to validate the hypotheses in the structural equation model. Findings indicate that technological innovation is the basis for the successful implementation of ICT and its application guarantees greater information availability and efficient management, leading to obtaining operating benefits in SC.

Keywords: structural equation model; information and communication technology; ICT integration

\section{Introduction}

Companies seek to optimize supply chain (SC) operations, and innovation is essential to ensure survival in the global market. Therefore, there is currently a frequent growing use of computer packages to support the control in a production system. Moreover, empirical evidence shows that most small and medium-sized enterprises (SMEs) implementing innovation activities will improve their production processes and, consequently, the financial income.

For such reason, information systems that generate knowledge that guide organizations towards a vision of "up-to-date information and communication technology (ICT) tools" should be investigated. These ICTs enable SC members to improve product flow, services, and information in real-time [1]. ICTs have evolved together with a complexity value chain (VC) of products or services offered by companies driven by economic and social changes and will increase in pace as they are applied in production systems [2].

ICTs provide mechanisms for companies to collect, store, access, share, analyze, and control information, improving SC performance [3]. Therefore, ICT facilitates the decisionmaking process to maximize business and SC profitability. However, social benefits are 
also obtained, increasing information and knowledge exchange, accident reduction rates, and better motivation in human resources.

From the beginning, David et al. [4] indicated that ICT integrated into SC offers a reduction in cycle times and inventories, minimizes the whiplash effect, and allows collaboration among SC partners, among others. Here, ICT integration can be defined as the degree to which information systems are related to the company's internal functions and with SC members [3,5]. According to Llach and Alonso-Almeida [6], ICTs increase the efficiency of the organization's internal processes and the SC integration, facilitate the activities redesign, improving time, practicality, and accuracy.

These benefits are obtained since ICT facilitates the electronic data interchange (EDI) in real-time and the decision-making process in SC [7]. Therefore, using ICT in production processes, combined with human skills, generates Operating benefits in the SC, such as improving the process execution, management, and materials availability, decreasing information cost, improving quality by providing access to information, and increasing competitiveness [6].

In the last three decades, Mexico has had a boom in ICT adoption. Several types of research have studied this phenomenon in SC, associated with integration and Information management through causal models; other investigations analyze the critical factors for its implementation, such as Technological innovation, Information availability, and Information management [8,9].

Although Hallikas, Korpela, Vilko and Multaharju [1] mention that integrated process activities using ICT, information gathering, and sharing in SC must be studied, they recognize that there is not enough information on ICT control and management in SC. In addition, there is little empirical evidence on the contribution of ICT in SC performance in SMEs, so there is a need to improve the understanding of the impact of using ICT in SC, where the lag of technology has left a wide gap.

One SME sector with ICT widely applied is the maquiladora industry (MI), which is defined as a subsidiary company with its headquarters in a country other than the one in which it is established. Specifically, there are 5171 companies of this type in Mexico, generating 2,702,116 direct jobs and are based mainly on the country's northern part [10]. Those MI are close to the United States of America as the primary world market and take advantage of skilled and low-cost labor and tariff preferences due to free trade agreements between the two countries.

Specifically, in Baja California state (Mexico), there are 931 MIs, which generate 358,889 direct jobs, with Tijuana and Mexicali being the most representative cities, with 72,605 and 252,902 direct jobs, respectively [11]. This MI is characterized by importing its raw materials and exporting its finished products. Hence, communication with customers and suppliers outside the MI is intense due to their geographical characteristics and internal departments. Therefore, for SMEs, ICT is essential in their production and administrative processes for information flow horizontally and vertically.

However, even given the importance of IM in Baja California, few studies have focused on studying the ICT implementation. The most representative research by Pérez-López et al. [12] focuses on investigating the relationship between the planning process and the operational benefits obtained. Other studies in the region focus on studying ICT in other sectors, such as education [13], restaurants [14], or the integration of a cluster specialized in ICT [15].

Hence, this article aims to analyze three critical success factors in ICT implementation in MI in Baja California (Mexico): Technological innovation, Information availability, and Information management as independent variables, and to determine their impact on Operating benefits obtained in the SC as the dependent variable.

\section{Literature Review and Hypotheses}

\subsection{Technological Innovation (TIN)}

Technological innovation is defined as a kind of goods or services. Due to its novelty or degree of improvement, it will benefit end-users and meet their needs [16]. In addition, 
these innovations in the implementation and adoption processes develop new knowledge through internal engineering and development departments and the interaction of the company with external partners, such as society, government, clients, and suppliers [17].

For companies, innovation is vital to increase productivity and raise the competitiveness of their processes, so there is a need to promote and encourage ICTs to perform business. Orji et al. [18] express that innovation has a positive effect on SC economic performance.

\subsection{Information Availability (IAV)}

Information is essential for decision-making in any business. The availability, speed, accuracy, and visibility of this information are vital, and its analysis is currently part of the administrative tasks in SC [1]. Dutta et al. [19] point out that companies have integrated ICT devices to acquire, control, coordinate, and manage information from their operational processes, facilitating the decision-making process in Indian manufacturing companies. Therefore, Technological innovation used in SC allows having Information availability to link activities in production processes [20], so the following hypothesis is proposed:

Hypothesis 1 (H1). Technological innovation in SC has a direct and positive effect on Information availability in SMEs.

\subsection{Information Management (IMA)}

Information is commonly used for decision-making. That is, it is managed to improve customer relationship management (CRM). IMA has been developed in recent years, combined with strategy and technology to create, improve customer and supplier relationships, which maximizes the value generated, trust, and cooperation between partners. Thus, Information management is a competitive advantage for companies with more dynamic processes and supports a quick response to uncertainty [21]. However, this Information management depends on the levels of Technological innovation that the company has, so the following hypothesis is proposed:

Hypothesis 2 (H2). Technological innovation in SC has a direct and positive effect on Information management performed in SMEs.

Madonsela [22] states that investors trust that Information management with the use of ICT guarantees return on investment (ROI), while Llach and Alonso-Almeida [6] state that human ability is increased. However, Information availability allows partners to share operational, tactical, and strategic information to decrease uncertainty in SC, hence its importance. Some authors mention that the alliance between Information availability and Information management is fundamental for the success of companies [23]. In addition, some state that Information management for mutual growth among organizations depends on the accessibility to information, so the following hypothesis is proposed:

Hypothesis 3 (H3). Information availability in SC has a direct and positive effect on Information management in SMEs.

\subsection{Operating Benefits (OBE)}

Integrating and using ICT in SC to interact and coordinate activities generates Operating benefits in the short and long term [7], which means that logistics and transport operations are places to share and transfer data, thus improving operational performance.

Haj and Dhiaf [20] conclude that managers should be aware of the benefits of integrating ICT and performance improvement in their operations. In this sense, ICT is identified as the innovation to perform information exchange among companies, depending on the companies' technological and partners' integration level. Moreover, Madonsela [22] indicates that companies that invest and use innovative ICT grow faster and are more productive and profitable. Therefore, the following hypothesis is proposed: 
Hypothesis 4 (H4). Technological innovation in SC has a direct and positive effect on the Operating benefits obtained by SMEs.

Obtaining information from the SC is not enough. It must be available for the SC members to facilitate decision-making and generate operational performance in terms of time savings in task executions, reduction of errors by handling information, and, above all, lower costs [1]. Kumar et al. [24] agree that ICT integration in production processes and Information availability add value to the product or service, affecting operations, customers, suppliers, and internal collaborators, so the following hypothesis is proposed:

Hypothesis 5 (H5). Information availability in SMEs has a direct and positive effect on Operating benefits.

Petrick, Maitland and Pogrebnyakov [7] indicate that Information management in the company's operational areas produces benefits and allows supervision, management, and operations control. Likewise, Partanen et al. [25] mention that most industries implement ICT to generate competitive advantage, which leads to business development and management of the organization's information system. At the same time, one of the leading Operating benefits offered by Information management within the SC comes from coordinated decision making, as it is the key to finding a skillful SC [25-27]. Therefore, the following hypothesis is proposed:

Hypothesis 6 (H6). Information management in SC directly and positively affects the Operating benefits obtained in SMEs.

Figure 1 graphically represents the hypotheses regarding the analysis variables mentioned above.

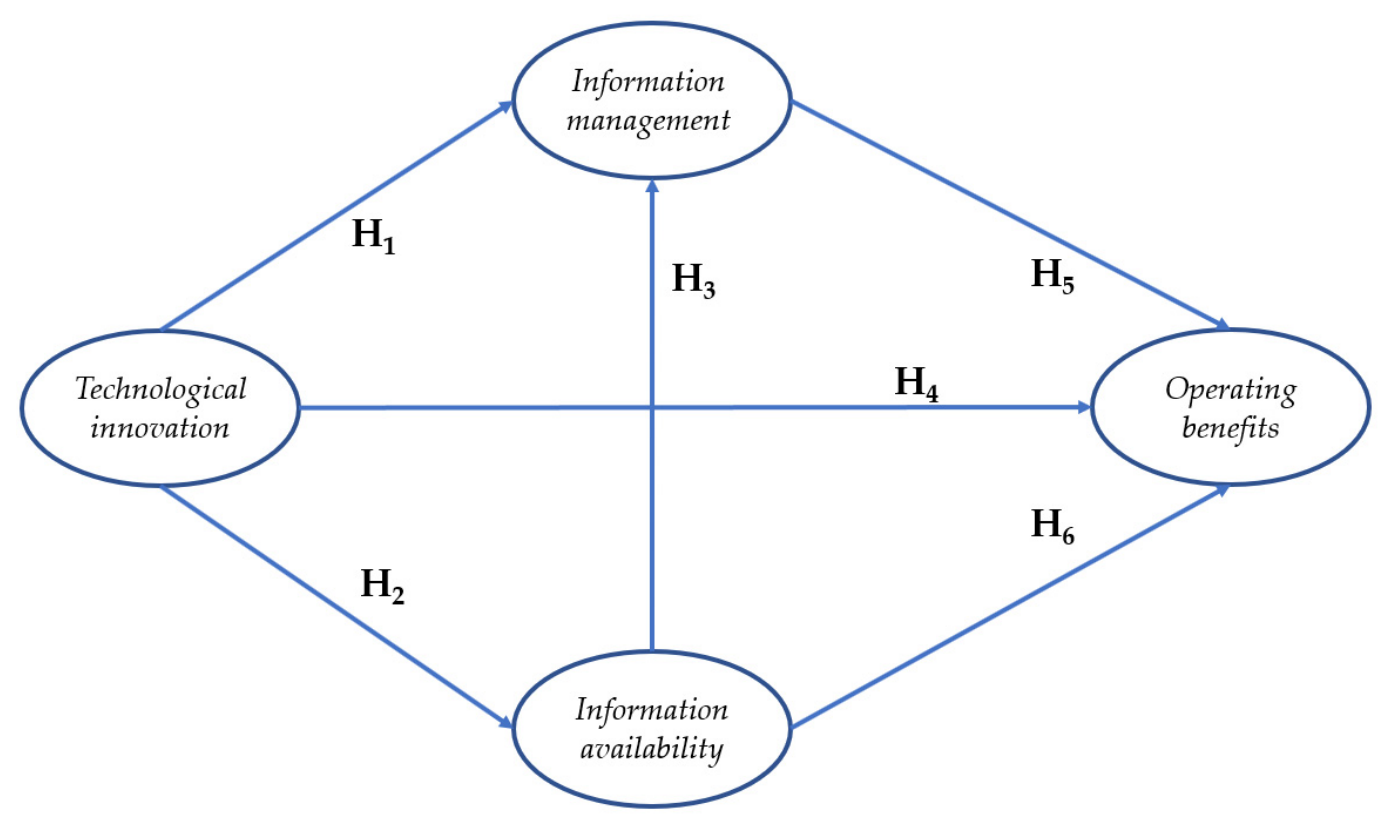

Figure 1. Proposed hypotheses.

\section{Methodology}

3.1. Questionnaire Preparation

A questionnaire was designed to obtain information about using ICT in SC activities in SMEs in Baja California, Mexico. Databases such as Elsevier, SpringerLink, Emerald, and EBSCOhost were consulted for generating the questionnaire. The scientific articles selection 
related to ICT was made using these keywords: ICT integration, ICT adoption, and ICT in SC. A list with 145 articles was obtained and reviewed but was reduced to only 55. In addition, only articles written in English and published in indexed journals were analyzed.

The questionnaire was integrated into six sections, and the first section sought to obtain demographic information associated with the respondent, industrial sector, respondent's profile, and age. From the second to the fourth section, information on the planning, execution, and control of ICT in the SC were obtained; the fifth and sixth sections were related to the benefits, with 91 items. However, in this report, only items corresponding to the control stage were analyzed, where the following latent variables were studied:

1. Technological innovation, with four items $[17,20]$

2. Information availability, with eight items $[1,5,20,26]$

3. Information management, with eight items $[6,21,22,25]$

4. Operating benefits, with five items $[1,7,20,22,25,26]$

The list of items belonging to each latent variable appears in the descriptive analysis of the items (Results section), but they were omitted here due to space restrictions.

\subsection{Application and Data Capture}

The questionnaire was uploaded to the Google forms platform for its application. The items must be answered using a five-point Likert scale. One indicates that the activity is not performed or that no benefits are obtained. Five means that this activity is always performed or that the benefit is always obtained [28]. Several authors have used that scale in productivity and manufacturing research in recent years $[29,30]$.

An email was sent to managers identified in Baja California (Mexico) laboring for SMEs, explaining the study's objective and inviting them to participate. The platform was available from January to April 2020 to collect responses.

\subsection{Debugging of the Database}

An Excel file was downloaded from the platform, and questionnaires with duplicate responses were identified and discarded for future analysis. Missing and extreme values were determined and replaced by the median [31]; likewise, the standard deviation of each case (questionnaire answered) was obtained for non-compromised responders identification, and those with values lower than 0.5 were discarded from the analysis.

\subsection{Validation of Variables}

Latent variables were validated according to the following indexes [32]: R-squared and adjusted R-squared to measure parametric predictive validity, and values greater than 0.2 were accepted; $Q$-squared to measure nonparametric predictive validity, and values greater than zero, and similar to R-squared were taken; Cronbach's alpha and composite reliability index to measure internal validity, and values larger than 0.7 were accepted; average variance extracted (AVE) for convergent validity and values greater than 0.5 were accepted; variance inflation factor (VIF) to measure collinearity, and values lower than 3.3 were taken.

\subsection{Descriptive Analysis of the Sample}

A descriptive analysis was performed with the debugged database in the SPSS $23^{\circledR}$ statistical software due to its wide acceptance, friendly interphase, and use in scientific reports $[33,34]$. This analysis was performed with the demographic information obtained which makes it possible to characterize the sample using crosstabs.

\subsection{Descriptive Analysis of Items}

Central tendency and dispersion measures for items in latent variables were obtained. The median was obtained to measure central tendency, given that data are received on an ordinal scale as an assessment. High median values indicate that activities are always 
performed, or that benefits are always obtained, while low values indicate the opposite. The arithmetic mean was not used because the values are not on an interval scale [30].

As a measure of dispersion for every item, the interquartile range (IR) was obtained. A high value indicates low consensus among the surveyed persons about the value in an item, while low values indicate high agreement.

\subsection{Structured Equation Modelling (SEM)}

To validate hypotheses in Figure 1, the WarpPLS $5.0^{\circledR}$ software was used based on partial least squares (PLS), recommended for small samples by Kock [32]. Before interpreting the structural model, the following model efficiency indices with a significance level of 0.05 were evaluated [30]: average path coefficient (APC) to know the average predictive model validity; average R-squared and average adjusted R-squared (AARS) are measures of the explanatory power of the model; block average variance inflation index (AVIF) and VIF full collinearity index (AFVIF), which measures the collinearity between items in a latent variable, the ideal value should be less than 3.3; Tenenhaus index (GoF), which measures data fit to the model, the appropriate value should be greater than 0.36 .

To validate the relationships or hypotheses, the direct effects between latent variables were measured (see Figure 1), estimating a standardized regression index $\beta$ and tested using the following null hypothesis: $\beta i=0$ versus the alternative hypothesis: $\beta i \neq 0$. If the hypothesis test indicates that $\beta i \neq 0$, then there is statistical evidence to declare a relationship between two variables.

The relationship between the latent variables was measured by these three types of effects $[30,35]$ : direct effects indicate the impact between latent variables and validate the hypotheses proposed; indirect effects between variables occur through a third variable called mediator, and at least one mediator can appear. Total effects are the sum of direct and indirect effects in each relationship analyzed.

\subsection{Sensitivity Analysis}

A sensitivity analysis was performed to determine the situations in certain scenarios of latent variable occurrence. In this case, since PLS uses standardized values for estimations, a probability less than minus one in a latent variable is considered low scenario $P\left(X_{i}<-1\right)$. In contrast, a probability greater than one is a high scenario $P\left(X_{i}>1\right)$ [32]. Thus, conditional probabilities for the following scenarios were estimated for each relationship: $\mathrm{P}\left(\mathrm{Z}_{\mathrm{d}}>1\right) / \mathrm{P}\left(\mathrm{Z}_{\mathrm{i}}>1\right), \mathrm{P}\left(\mathrm{Z}_{\mathrm{d}}>1\right) / \mathrm{P}\left(\mathrm{Z}_{\mathrm{i}}<-1\right), \mathrm{P}\left(\mathrm{Z}_{\mathrm{d}}<-1\right) / \mathrm{P}\left(\mathrm{Z}_{\mathrm{i}}>1\right)$ and $\mathrm{P}\left(Z_{\mathrm{d}}<-1\right) / \mathrm{P}\left(Z_{\mathrm{i}}<-1\right)$; where, $Z_{\mathrm{d}}$ represents the standardized value for a dependent variable, and $Z_{\mathrm{i}}$ is for the independent variable. Moreover, probabilities of find variables co-occurring in high and low scenarios were reported, whereby we obtain: $\mathrm{P}\left(Z_{i}>1\right)$ $\cap \mathrm{P}\left(\mathrm{Z}_{\mathrm{d}}>1\right), \mathrm{P}\left(\mathrm{Z}_{\mathrm{i}}>1\right) \cap \mathrm{P}\left(\mathrm{Z}_{\mathrm{d}}<-1\right), \mathrm{P}\left(\mathrm{Z}_{\mathrm{i}}<-1\right) \cap \mathrm{P}\left(\mathrm{Z}_{\mathrm{d}}>1\right)$ and $\mathrm{P}\left(\mathrm{Z}_{\mathrm{i}}<-1\right) \cap \mathrm{P}$ $\left(Z_{\mathrm{d}}<-1\right)$.

\section{Results}

\subsection{Descriptive Analysis of the Sample}

After debugging the database, 80 valid surveys were obtained from different SMEs established in Baja California, Mexico. Table 1 illustrates the descriptive analysis, indicating the industrial sector and the respondent's position. We observed that manufacturing industries represent $45 \%$ of participation, and the sectors of the food, textile, computer equipment, and electronic accessories industries represent $35 \%$; the other sectors only hold $20 \%$. Regarding the job position, supervisors represent $44 \%$, general managers with $30 \%$, and production managers with $26 \%$. 
Table 1. Industrial sector and job position.

\begin{tabular}{ccccc}
\hline Sector & $\begin{array}{c}\text { General } \\
\text { Managers }\end{array}$ & $\begin{array}{c}\text { Production } \\
\text { Manager }\end{array}$ & Supervisor & Total \\
\hline Manufacturing industries & 8 & 11 & 17 & 36 \\
Food industries & 4 & 1 & 2 & 7 \\
Textile industries & 2 & 5 & 0 & 7 \\
$\begin{array}{c}\text { Computer equipment } \\
\text { manufacturing }\end{array}$ & 1 & 1 & 5 & 7 \\
$\begin{array}{c}\text { Electronic accessories } \\
\text { manufacturing }\end{array}$ & 2 & 1 & 4 & 7 \\
$\quad \begin{array}{c}\text { Plastic industries } \\
\text { Metal product industries }\end{array}$ & 1 & 2 & 3 & 6 \\
Printing and related & 2 & 0 & 1 & 3 \\
$\quad$ industries & 2 & 0 & 0 & 1 \\
$\begin{array}{c}\text { Non-metallic mineral } \\
\text { industries }\end{array}$ & 1 & 0 & 0 & 1 \\
Furniture, mattresses, and & 1 & 0 & 35 & 80 \\
blinds industries & 24 & 21 &
\end{tabular}

Table 2 shows the years of experience in the job and the gender. Results indicate that $37 \%$ of responders had less than two years of experience, followed by $33 \%$ of responders with 2 to 4 years, and $24 \%$ of those with more than five years. With regards to gender, women participated with $32 \%$, while men participated with $68 \%$.

Table 2. Years on the position.

\begin{tabular}{cccccc}
\hline \multirow{2}{*}{ Sex } & \multicolumn{6}{c}{ Time } \\
\cline { 2 - 6 } & $<$ Years & 2-5 Years & 5-10 Years & >10 Years & Total \\
\hline Male & 18 & 21 & 7 & 8 & 54 \\
Female & 12 & 6 & 3 & 5 & 26 \\
Total & 30 & 27 & 10 & 13 & 80 \\
\hline
\end{tabular}

\subsection{Variables Validation}

Table 3 shows the values obtained from the variable validation process. According to the methodology proposed, the model has parametric predictive validity because Rsquared and adjusted R-squared are greater than 0.2. Overall, the variables comply with all the required validation indices (please see the cut-off value column).

\subsection{Descriptive Analysis}

Table 4 shows the median and interquartile range for items analyzed in latent variables. The second column illustrates the median. It is observed that six items have values greater than four, indicating that, based on the respondent's perception, those activities are essential and frequently performed in the company, or the benefits are commonly gained. Two values that are larger than four are associated with Information availability, and four are related to the Operating benefits gained. However, the lowest median value is related to items search for and renew the most modern information technology, and this means that SMEs have insufficient resources for renewing ICT frequently. 
Table 3. Validation indexes for latent variables.

\begin{tabular}{cccccc}
\hline \multirow{2}{*}{ Indices } & \multirow{2}{*}{ Cut-Off Value } & \multicolumn{4}{c}{ Latent Variables } \\
\cline { 3 - 5 } & & TIN & IAV & IMA & OBE \\
\hline R-squared & $\geq 0.2$ & & 0.61 & 0.529 & 0.757 \\
Adjusted R-squared & $\geq 0.2$ & & 0.605 & 0.517 & 0.748 \\
Reliability index & $\geq 0.7$ & 0.951 & 0.920 & 0.889 & 0.956 \\
Cronbach's Alpha & $\geq 0.7$ & 0.939 & 0.895 & 0.750 & 0.908 \\
Average variance extracted & $\geq 0.5$ & 0.733 & 0.659 & 0.800 & 0.915 \\
Variance inflation index & $\leq 3.3$ & 3.231 & 2.832 & 2.378 & 3.816 \\
Q-squared & $\geq 0.2$ & & 0.611 & 0.529 & 0.758 \\
\hline
\end{tabular}

Table 4. Data descriptive analysis.

\begin{tabular}{|c|c|c|}
\hline Items & Median & Interquartile Range \\
\hline \multicolumn{3}{|l|}{ Technological innovation } \\
\hline $\begin{array}{c}\text { Keep a robust data network with suppliers and customers to } \\
\text { monitor and evaluate the exchange } \\
\text { of information }\end{array}$ & 3.745 & 1.748 \\
\hline Efficient use of data exchange & 3.714 & 1.695 \\
\hline Provide maintenance to the information system & 3.558 & 1.705 \\
\hline $\begin{array}{l}\text { Search for and renew the most modern } \\
\text { information technology }\end{array}$ & 3.533 & 1.921 \\
\hline \multicolumn{3}{|l|}{ Information availability for or from } \\
\hline Customer order follow-up & 4.164 & 1.413 \\
\hline Fulfillment and delivery order management & 4.018 & 1.478 \\
\hline From commercial customers & 3.904 & 1.507 \\
\hline Customer demand management & 3.887 & 1.502 \\
\hline Inventory management materials & 3.830 & 1.490 \\
\hline $\begin{array}{l}\text { Suppliers and customers in product } \\
\text { development processes }\end{array}$ & 3.745 & 1.621 \\
\hline Suppliers & 3.694 & 1.710 \\
\hline Management of supplier activities and relationships & 3.569 & 1.526 \\
\hline \multicolumn{3}{|l|}{ Information management } \\
\hline The Internet capacity of the organization & 3.977 & 1.620 \\
\hline They are providing high-quality services & 3.920 & 1.553 \\
\hline Purchase and sales systems & 3.863 & 1.575 \\
\hline The internal computer network system & 3.830 & 1.637 \\
\hline $\begin{array}{l}\text { The planning and scheduling of the } \\
\text { organization's activities }\end{array}$ & 3.808 & 1.567 \\
\hline The various internal information systems & 3.745 & 1.483 \\
\hline The software used in the information system & 3.725 & 1.635 \\
\hline Electronic market trends & 3.634 & 1.967 \\
\hline Warehouse management systems & 3.609 & 1.850 \\
\hline \multicolumn{3}{|l|}{ Operating benefits } \\
\hline Customer response flexibility & 4.123 & 1.609 \\
\hline Flexibility of the systems to meet customer needs & 4.091 & 1.630 \\
\hline Cost competitiveness & 4.038 & 1.745 \\
\hline Strengthening the relationship with customers & 4.000 & 1.629 \\
\hline Shorter order cycles & 3.878 & 1.820 \\
\hline
\end{tabular}


The third column illustrates the interquartile range. The highest IR value is 1.967, meaning that responders probably had doubts interpreting the electronic market trends. The lowest value is 1.397, referring to customer order follow-up; it indicates that there was a lot of agreement and consensus among respondents for the value in that item.

\subsection{Model Efficiency Indices}

The model efficiency indices appear in Table 5. The average path coefficient has a $p$-value lower than 0.001, indicating that the model has predictive validity. Similarly, the average R-squared (ARS) and adjusted R-squared (AARS) have an associated $p$-value lower than 0.001 , indicating that the model has sufficient explanatory power.

Table 5. Model efficiency indices.

\begin{tabular}{ccc}
\hline Indices & Results & Cut-Off Value \\
\hline Average path coefficient (APC) & $(\mathrm{APC})=0.422, p<0.001$ & $p \leq 0.05$ \\
Average R-squared (ARS) & $(\mathrm{ARS})=0.632, p<0.001$ & $p \leq 0.05$ \\
Average adjusted R-squared (AARS) & $(\mathrm{AARS})=0.623, p<0.001$ & $p \leq 0.05$ \\
Average block VIF (AVIF) & $(\mathrm{AVIF})=2.435$ & Acceptable if $\leq 3.3$ \\
Average full collinearity VIF (AFVIF) & $(\mathrm{AFVIF})=3.064$ & Acceptable if $\leq 3.3$ \\
Tenenhaus GoF (GoF) & $(\mathrm{GoF})=0.701$ & Better if $\geq 0.36$ \\
\hline
\end{tabular}

Moreover, the average block variance inflation factor index (AVIF) and the VIF full collinearity index (AFVIF) have values lower than 3.3, concluding that there are no collinearity problems among latent variables analyzed. Similarly, the Tenenhaus index (Gof) shows that model has a good data fit since its value is greater than 0.36 . Figure 2 illustrates the $\beta$, the $p$-value associated with relationships among latent variables as direct effects or hypotheses, and the $\mathrm{R}^{2}$.

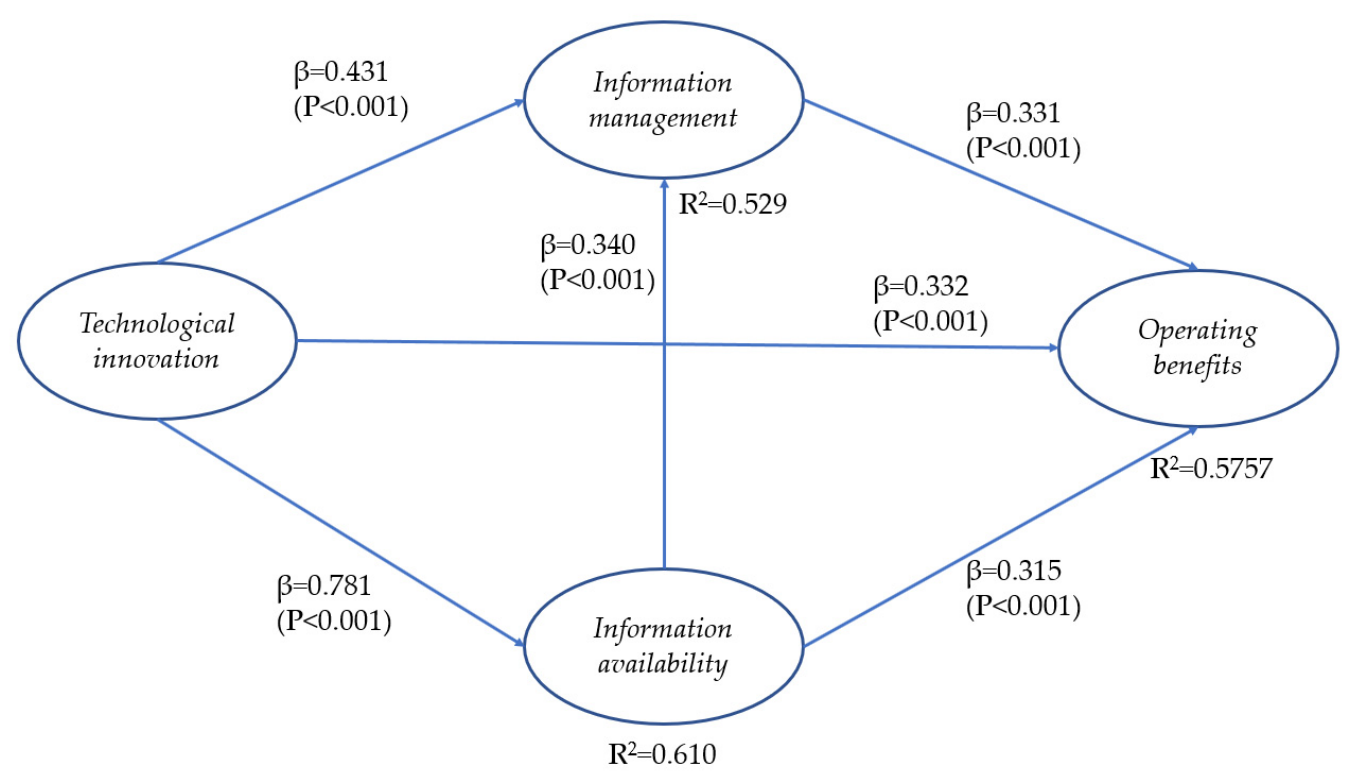

Figure 2. Structural equation model.

\subsection{Direct Effects}

Table 6 summarizes the results of direct effects between latent variables, indicating the associated $p$-value. According to the $p$-values associated with every $\beta$ estimated, it is concluded that all relationships tested must be accepted (see the last column named decision). For example, the following conclusion can be done for H1: there is enough statistical evidence to declare that Technological innovation in SC has a direct and positive 
effect on Information availability they possess in SMEs since when the first latent variable increases its standard deviation by one unit, the second one goes up by 0.781 units.

Table 6. Direct effects.

\begin{tabular}{ccccc}
\hline Hi & Independent Variable & Dependent Variable & $\boldsymbol{\beta}(\boldsymbol{p}$-Value $)$ & Decision \\
\hline H1 & Technological innovation & Information availability & $0.781(<0.001)$ & Accept \\
H2 & Technological innovation & Information management & $0.431(<0.001)$ & Accept \\
H3 & Information availability & Information management & $0.340(<0.001)$ & Accept \\
H4 & Technological innovation & Operating benefits & $0.332(<0.001)$ & Accept \\
H5 & Information availability & Operating benefits & $0.315(<0.001)$ & Accept \\
H6 & Information management & Operating benefits & $0.331(<0.001)$ & Accept \\
\hline
\end{tabular}

\subsection{Sum of Indirect Effects}

The sum of indirect effects among latent variables appears in Table 7, where two of them are statistically significant, and one is not. For example, the indirect relationship between Technological innovation and Information management given by Information availability as a mediator variable has $\beta=0.265$, with $p$-value $<0.001$, and is statistically significant. It is the same case for the relationship between Technological innovation and Operating benefits, which is given through Information availability and Information management as mediator variables and has $\beta=0.477$, and $p$-value $<0.001$, being statistically significant. On the contrary, the indirect relationship of Information availability to Operating benefits has $\beta=0.113$ with $p=0.073$ (greater than 0.05 ), so it is concluded that there are no indirect effects between those variables.

Table 7. Sum of indirect effects.

\begin{tabular}{ccc}
\hline \multirow{2}{*}{ To } & \multicolumn{3}{c}{ From } \\
\cline { 2 - 3 } & TIN & IAV \\
\hline$I M A$ & $0.265(p<0.001)$ & \\
OBE & $0.477(p<0.001)$ & $0.113(p=0.073)$ \\
\hline
\end{tabular}

\subsection{Total Effects}

Table 8 illustrates the total effects among variables and the associated $p$-value. It is observed that all the total effects are statistically significant, even though one of the indirect effects was not. For example, the relationship between Technological innovation and Operating benefits has a total effect of $\beta=0.809$ with $p$-value $<0.001$, indicating a significant total effect between those variables. We observed that the indirect relationship between Information availability and Operating benefits was statistically non-significant, but the direct effect and total effects were significant.

Table 8. Total effects.

\begin{tabular}{cccc}
\hline To & & From & \\
\cline { 2 - 4 } & TIN & IAV & IMA \\
\hline$I A V$ & $0.781(p<0.001)$ & & \\
$I M A$ & $0.697(p<0.001)$ & $0.340(p<0.001)$ & \\
$O B E$ & $0.809(p<0.001)$ & $0.428(p<0.001)$ & $0.331(p<0.001)$ \\
\hline
\end{tabular}

\subsection{Sensitivity Analysis}

Table 9 illustrates the results of the sensitivity analysis. In this case, the independent variables appear in columns and the dependent variables in rows. The conditional probability value is indicated by the term "If", while the joint or simultaneous probability is marked as " $\mathcal{E}$ ". Thus, the probability of finding TIN+ and IMA+ together is only 0.076 , but 
the probability of having IMA+, given that TIN+ has occurred, is 0.545 . However, if TIN+ has occurred, there is only a 0.091 probability of getting $I M A-$, which reassures managers that as long as they invest in innovative ICT, getting poor Information management has a low occurrence probability and guarantees ICT implementation. The other relationships between variables are interpreted similarly.

Table 9. Sensitivity analysis.

\begin{tabular}{|c|c|c|c|c|c|c|c|c|}
\hline & & & \multicolumn{2}{|c|}{ TIN } & \multicolumn{2}{|c|}{ IMA } & \multicolumn{2}{|c|}{ IAV } \\
\hline & & & + & - & + & - & + & - \\
\hline & & Value & 0.139 & 0.165 & 0.165 & 0.089 & 0.165 & 0.203 \\
\hline \multirow{4}{*}{ IMA } & \multirow{2}{*}{+} & \multirow{2}{*}{0.165} & $\&=0.076$ & $\&=0.013$ & & & & \\
\hline & & & If $=0.545$ & If $=0.091$ & & & & \\
\hline & \multirow{2}{*}{-} & \multirow{2}{*}{0.089} & $\&=0.013$ & $\&=0.063$ & & & & \\
\hline & & & If $=0.091$ & If $=0.385$ & & & & \\
\hline \multirow{4}{*}{ IAV } & \multirow{2}{*}{+} & \multirow{2}{*}{0.165} & $\&=0.076$ & $\&=0.000$ & $\&=0.089$ & $\&=0.000$ & & \\
\hline & & & If $=0.545$ & If $=0.000$ & If $=0.538$ & If $=0.000$ & & \\
\hline & \multirow{2}{*}{-} & \multirow{2}{*}{0.203} & $\&=0.000$ & $\&=0.101$ & $\&=0.013$ & $\&=0.051$ & & \\
\hline & & & If $=0.000$ & If $=0.615$ & If $=0.063$ & If $=0.250$ & & \\
\hline \multirow{4}{*}{ OBE } & \multirow{2}{*}{+} & \multirow{2}{*}{0.177} & $\&=0.101$ & $\&=0.000$ & $\&=0.089$ & $\&=0.013$ & $\&=0.101$ & $\&=0.000$ \\
\hline & & & If $=0.727$ & If $=0.000$ & If $=0.538$ & If $=0.143$ & If $=0.615$ & If $=0.000$ \\
\hline & \multirow{2}{*}{-} & \multirow{2}{*}{0.177} & $\&=0.000$ & $\&=0.114$ & $\&=0.000$ & $\&=0.076$ & $\&=0.000$ & $\&=0.076$ \\
\hline & & & If $=0.000$ & If $=0.692$ & If $=0.000$ & If $=0.857$ & If $=0.000$ & If $=0.375$ \\
\hline
\end{tabular}

\section{Conclusions}

Descriptive analysis in Table 4 indicates that MSME managers are sure about the benefits that ICTs offer in production and management systems. Four of the five items analyzed have medians higher than four, and the most important benefits are the flexibility they can have with customers. That assertion is confirmed by noting that the other items with a median greater than four are in the Information availability variable and are associated with customer order follow-up and order management and delivery times. In other words, managers focus on having a close relationship with their customers.

From the sensitivity analysis, the following can be concluded and recommended:

Managers should encourage the implementation of innovative ICT in their production, administrative, and SC systems, as this ensures adequate Information management $($ If $=0.545)$ and wide Information availability (If $=0.545$ ). In addition, Operating benefits are guaranteed at high levels (If $=0.727$ ). However, if there are low ICT innovative levels, then it is probable to have low levels of Information management (If $=0.385)$ and Information availability (If $=0.615)$, and also Operating benefits are not guaranteed (If $=0.692$ ).

Companies that achieve an adequate and high level of Information management can guarantee a higher Information availability (If $=0.538$ ) and obtain Operating benefits (If $=0.538)$. However, if they do not achieve adequate Information management, in that case, they may have a low Information availability (If $=0.250)$ and, above all, they may not obtain the expected Operating benefits (If $=0.857$ ), which represents a high risk.

Finally, companies with higher Information availability always obtain higher Operating benefits (If $=0.615$ ), and there is no possibility of these being low (If $=0.000)$. Likewise, if there are low levels of Information availability, in that case, high levels of Operating benefits (If $=0.000$ ) can never be obtained. On the contrary, there is a possibility that these will be low $($ If $=0.375)$. 
Regarding the six hypotheses initially proposed, all have been statistically tested, and based on this, the following inferences are made:

The MI as SMEs in Baja California, Mexico should focus their efforts on achieving an adequate level of implementation of innovative ICT in their production and supply chain systems. That effort enables them to facilitate relationships with suppliers, customers, government and society, and departments within the company by managing inventories, tracking orders, and delivery time, as shown in hypothesis $\mathrm{H}_{1}$. In other words, this means that MIs in Baja California are currently developing a digital environment by incorporating ICT in SC activities and managing information in SC operations through appropriate technology, and greater competitiveness and productivity indexes are obtained. Hence, collaborators in the production processes and the SC members are motivated since they have reliable and timely information to implement activities and control operations, reducing uncertainty.

The integration of innovative ICT in SC activities represents a potential opportunity for MIs; however, the information generated should be made available cautiously to other members, as demonstrated by hypothesis $\mathrm{H}_{2}$. The practical implication is that MIs are not excluded from integrating concepts and technology of Industry 4.0 because the Technological innovation level is directly related to higher sales and online purchases and inventory management. Our findings are also empirical support to Toudert [36], who mentions that despite the digital gap in Mexico, companies show interest in integrating ICTs, which is reflected in more excellent digital communication and having more information related to their production systems.

The information must be available, but there must be adequate management of it, as demonstrated statistically and empirically in hypothesis $\mathrm{H}_{3}$. These findings are similar to those reported by Durugbo [37], who also indicates that this information must be accurate, complete, transparent, and rapidly disseminated to all concerned parties. Likewise, AvelarSosa, García-Alcaraz, Cedillo-Campos and Adarme-Jaimes [29], indicate that Information availability minimizes the SC risk level due to good communication among members.

Undoubtedly, implementing ICT in administrative, productive, and SC systems requires a robust economic investment, considered by many companies as a risk. Our research shows that Technological innovation is directly related to the Operating benefits obtained, as indicated by hypothesis $\mathrm{H}_{4}$. In other words, ICTs allow companies to generate better flexibility to meet customer needs since many times they must only reschedule production programs, allowing shorter order cycles and having more extensive market coverage. Our findings coincide with García-Alcaraz et al. [38]. They indicate that ICTs implementation speeds up the new product development process. In global terms, Appiah-Otoo and Song [39] associate ICTs with the overall growth of countries.

Having ICTs in production and administrative systems to obtain information is not enough. The justification of these ICTs is only achieved if this information is available and generates benefits. Our study has shown statistically and empirically that these two variables are related, as indicated in hypothesis $\mathrm{H}_{5}$. Our findings agree with Ali and Kumar [40], who suggest that ICTs have favored farmers' decision-making process in SC, while Ansola et al. [41] point out that ICTs have improved airport operations.

In conclusion, it has been statistically proven that proper Information management impacts the Operating benefits obtained and that the information systems implemented by the MI favor cost competitiveness and strengthen the relationships with customers and suppliers in a closer way.

\section{Limitations and Future Research}

This research has reported the ICT control process in MI and the operational benefits, where it is assumed that the planning and implementation processes have already been carried out. However, future research requires an integrative structural equation model in which all stages of the ICT adoption process are analyzed. 
Moreover, only the operational benefits have been analyzed in this report; however, the economic benefits obtained should also be explored. Thus, future research will be focused on social and commercial benefits and how these are converted into higher financial incomes.

Author Contributions: Conceptualization, J.E.O.-T. and R.J.P.-L.; methodology, R.J.P.-L. and J.L.G.-A.; software, J.L.G.-A.; validation, M.M.-M. and C.C.-W.; formal analysis, J.L.G.-A. and J.A.L.-B.; investigation, R.J.P.-L.; resources, J.E.O.-T.; data curation, M.M.-M.; writing-original draft preparation, J.L.G.-A. and J.A.L.-B.; writing-review and editing, J.L.G.-A.; visualization, M.M.-M.; supervision, J.E.O.-T.; project administration, J.E.O.-T.; funding acquisition. All authors have read and agreed to the published version of the manuscript.

Funding: This research was funded by the Mexican National Council for Science and Technology (CONACYT) with a scholarship for Rubén Jesús Pérez-López (grant: 542000) and María Mojarro Magaña (grant: 541999) for their doctoral studies at the Autonomous University of Baja California.

Institutional Review Board Statement: Not applicable.

Informed Consent Statement: Not applicable.

Data Availability Statement: The database containing the information analyzed in the structural equation model is available in an Excel sheet at this doi:10.17632/pssdjd5fxx.1.

Acknowledgments: No applicable.

Conflicts of Interest: The authors declare no conflict of interest.

\section{References}

1. Hallikas, J.; Korpela, K.; Vilko, J.; Multaharju, S. Assessing Benefits of Information Process Integration in Supply Chains. In Proceedings of the Procedia Manufacturing, Chicago, IL, USA, 9-14 August 2019; pp. 1530-1537.

2. Al-Gahtani, S.S. Empirical investigation of e-learning acceptance and assimilation: A structural equation model. Appl. Comput. Inform. 2016, 12, 27-50. [CrossRef]

3. Swafford, P.M.; Ghosh, S.; Murthy, N. Achieving supply chain agility through IT integration and flexibility. Int. J. Prod. Econ. 2008, 116, 288-297. [CrossRef]

4. David, S.-L.; Philip, K.; Edith, S.-L. Designing and Managing the Supply Chain: Concepts Strategies and Case Studies; McGraw Hill: New York, NY, USA, 2000.

5. Li, S.; Lin, B. Accessing information sharing and information quality in supply chain management. Decis. Support. Syst. 2006, 42, 1641-1656. [CrossRef]

6. Llach, J.; Alonso-Almeida, M.D.M. Integrating ICTs and Supply Chain Management: The Case of Micro-Sized Firms. Hum. Factors Ergon. Manuf. Serv. Ind. 2015, 25, 385-397. [CrossRef]

7. Petrick, I.; Maitland, C.; Pogrebnyakov, N. Unpacking Coordination Benefits in Supply Networks: Findings from Manufacturing SMEs. J. Small Bus. Manag. 2016, 54, 582-597. [CrossRef]

8. Martínez-Domínguez, M.; Mora-Rivera, J. Internet adoption and usage patterns in rural Mexico. Technol. Soc. 2020, 60, 101226. [CrossRef]

9. Cuevas-Vargas, H.; Estrada, S.; Larios-Gómez, E. The Effects of ICTs As Innovation Facilitators for a Greater Business Performance. Evidence from Mexico. Procedia Comput. Sci. 2016, 91, 47-56. [CrossRef]

10. IMMEX. INDEX Juárez-Monthly Statistic Information (22 January 2021); Asociación de Maquiladoras A.C.: Ciudad Juárez, Mexico, 2021; pp. 1-3.

11. IMMEX. Monthly Statistical Information-Employment; Maquiladora Association A.C.: Ciudad Juárez, Mexico, $2021 ;$ p. 4.

12. Pérez-López, R.J.; Olguín Tiznado, J.E.; Mojarro Magaña, M.; Camargo Wilson, C.; López Barreras, J.A.; García-Alcaraz, J.L. Information Sharing with ICT in Production Systems and Operational Performance. Sustainability 2019, 11, 3640. [CrossRef]

13. Sandoval Bringas, J.A.; Carreño León, M.A.; Alvarez Rodriguez, F.J. Analysis of the Perception of Students of the Autonomous University of Baja California Sur for the Use of m-Learning. In Advances in Intelligent Systems and Computing; AISC: Chicago, IL, USA, 2021; Volume 1192, pp. 102-108.

14. Cruz Estrada, I.; Miranda Zavala, A.M. ICT adoption in restaurants in Puerto Nuevo, Rosarito, Baja California. Rev. Innovar 2019, 29, 59-75. [CrossRef]

15. Sánchez, C.A.F.; Lagarda, A.M.; Angulo, N.R.; Barceló, J.G.A. The construction of the ICT cluster in the regional development of Baja California. Interciencia 2017, 42, 132-139.

16. Zhai, X.; An, Y. The relationship between technological innovation and green transformation efficiency in China: An empirical analysis using spatial panel data. Technol. Soc. 2021, 64, 101498. [CrossRef]

17. Lema, R.; Quadros, R.; Schmitz, H. Reorganising global value chains and building innovation capabilities in Brazil and India. Res. Policy 2015, 44, 1376-1386. [CrossRef] 
18. Orji, I.J.; Kusi-Sarpong, S.; Gupta, H. The critical success factors of using social media for supply chain social sustainability in the freight logistics industry. Int. J. Prod. Res. 2020, 58, 1522-1539. [CrossRef]

19. Dutta, G.; Kumar, R.; Sindhwani, R.; Singh, R.K. Digital transformation priorities of India's discrete manufacturing SMEs-a conceptual study in perspective of Industry 4.0. Compet. Rev. Int. Bus. J. 2020, 30, 289-314. [CrossRef]

20. Haj, K.A.; Dhiaf, M.M. Do information and communication technologies affect the performance of a supply chain? Pieces of evidence from the Tunisian food sector. Yugosl. J. Oper. Res. 2019, 29, 539-552. [CrossRef]

21. Saleem, H.; Li, Y.; Ali, Z.; Ayyoub, M.; Wang, Y.; Mehreen, A. Big data use and its outcomes in supply chain context: The roles of information sharing and technological innovation. J. Enterp. Inf. Manag. 2020, 33. [CrossRef]

22. Madonsela, N.S. Integration of the Management Information System for Competitive Positioning. Procedia Manuf. 2020, 43, 375-382. [CrossRef]

23. Van Wijk, R.; Jansen, J.J.; Lyles, M.A. Inter-and intra-organizational knowledge transfer: A meta-analytic review and assessment of its antecedents and consequences. J. Manag. Stud. 2008, 45, 830-853. [CrossRef]

24. Kumar, R.; Singh, R.K.; Shankar, R. Critical success factors for implementation of supply chain management in Indian small and medium enterprises and their impact on performance. Iimb Manag. Rev. 2015, 27, 92-104. [CrossRef]

25. Partanen, J.; Kohtamäki, M.; Patel, P.C.; Parida, V. Supply chain ambidexterity and manufacturing SME performance: The moderating roles of network capability and strategic information flow. Int. J. Prod. Econ. 2020, 221, 107470. [CrossRef]

26. Nisar, T.M.; Prabhakar, G.; Strakova, L. Social media information benefits, knowledge management and smart organizations. J. Bus. Res. 2019, 94, 264-272. [CrossRef]

27. Garcia-Alcaraz, J.L.; Maldonado-Macias, A.A.; Alor-Hernandez, G.; Sanchez-Ramirez, C. The impact of information and communication technologies (ICT) on agility, operating, and economical performance of supply chain. Adv. Prod. Eng. Manag. 2017, 12, 29-40. [CrossRef]

28. Al-Tahat, M.D.; Bataineh, K.M. Statistical analyses and modeling of the implementation of agile manufacturing tactics in industrial firms. Math. Probl. Eng. 2012, 2012. [CrossRef]

29. Avelar-Sosa, L.; García-Alcaraz, J.L.; Cedillo-Campos, M.G.; Adarme-Jaimes, W. Effects of regional infrastructure and offered services in the supply chains performance: Case Ciudad Juarez. Dyna 2014, 81, 208-217. [CrossRef]

30. García-Alcaraz, J.L.; Prieto-Luevano, D.J.; Maldonado-Macías, A.A.; Blanco-Fernández, J.; Jiménez-Macías, E.; Moreno-Jiménez, J.M. Structural equation modeling to identify the human resource value in the JIT implementation: Case maquiladora sector. Int. J. Adv. Manuf. Technol. 2015, 77, 1483-1497. [CrossRef]

31. Hoffman, J.I.E. Chapter 9-Outliers and Extreme Values. In Basic Biostatistics for Medical and Biomedical Practitioners, 2nd ed.; Hoffman, J.I.E., Ed.; Academic Press: Boston, MA, USA, 2019; pp. 149-155. [CrossRef]

32. Kock, N. WarpPLS User Manual: Version 6.0; ScriptWarp Systems: Laredo, TX, USA, 2017; p. 141.

33. Avelar-Sosa, L.; García-Alcaraz, J.L.; Vergara-Villegas, O.O.; Maldonado-Macías, A.A.; Alor-Hernández, G. Impact of traditional and international logistic policies in supply chain performance. Int. J. Adv. Manuf. Technol. 2014, 76, 913-925. [CrossRef]

34. García-Alcaraz, J.L.; Macías, A.A.M.; Luevano, D.J.P.; Fernández, J.B.; López, A.J.G.; Macías, E.J. Main benefits obtained from a successful JIT implementation. Int. J. Adv. Manuf. Technol. 2016, 86, 2711-2722. [CrossRef]

35. Ketchen, D.J. A Primer on Partial Least Squares Structural Equation Modeling; Sage publications: Thousand Oaks, CA, USA, 2013. [CrossRef]

36. Toudert, D. Brecha digital, uso frecuente y aprovechamiento de Internet en México. Convergencia 2019, 26. [CrossRef]

37. Durugbo, C. Managing information for collaborative networks. Ind. Manag. Data Syst. 2014, 114, 1207-1228. [CrossRef]

38. García-Alcaraz, J.L.; Maldonado-Macías, A.A.; Sánchez-Ramírez, C.; Latorre-Biel, J.-I. Role of product, market, and organisational characteristics on NPD benefits. Int. J. Prod. Dev. 2018, 22, 421-440. [CrossRef]

39. Appiah-Otoo, I.; Song, N. The impact of ICT on economic growth-Comparing rich and poor countries. Telecommun. Policy 2021, 45,102082 . [CrossRef]

40. Ali, J.; Kumar, S. Information and communication technologies (ICTs) and farmers' decision-making across the agricultural supply chain. Int. J. Inf. Manag. 2011, 31, 149-159. [CrossRef]

41. Ansola, P.G.; Higuera, A.G.; de las Morenas, J.; García-Escribano, J. Decision Making Platform Supported on ICTs: Application to the Management of Ground Handling Operations at an Airport. IFAC Proc. Vol. 2011, 44, 13074-13079. [CrossRef] 